\title{
The Gulf Cooperation Council between Unity and Discord towards the Arab Uprisings
}

\author{
Linda Berger*
}

\begin{abstract}
The Gulf Cooperation Council, founded in 1981 by Bahrain, Kuwait, Oman, Qatar, Saudi Arabia and the United Arab Emirates, does not focus on economic, political or military cooperation. Instead, the GCC was established as a symbolic organisation of unity against the ideational threat from anti-monarchical Iranian and Iraqi ideologies. The Arab uprisings pose a new dire ideational threat: popular protests toppling authoritarian leaders. As I analyse in three case studies, the GCC does not reflect a united stance amongst its members and has become a symbol of discord.
\end{abstract}

Keywords: Gulf region, Saudi Arabia, Qatar, Arab uprisings, regime survival

Stichworte: Golfregion, Saudi-Arabien, Katar, Arabische Aufstände, Regimeerhalt

\section{Introduction}

S ince the beginning of the Arab uprisings and the toppling of authoritarian rulers in 2011, the six members of the Arab Gulf Cooperation Council (GCC), Kuwait, Bahrain, Qatar, UAE, Oman and Saudi Arabia, face acute ideational threats. In the 1980s, the ideational threat came from domestic dissidents inspired by post-revolutionary Iran and socialist Iraq. At present, the monarchies, with the exception of Qatar, feel threatened by domestic dissidents inspired by the Arab uprisings in Tunisia and Egypt.

Instead of the appearance of unity in the 1980s, the GCC has become a symbol of discord. At first glance, the GCC member states share the same historical, cultural, political and economic features and should thus employ the same foreign policy strategies. But a closer look reveals diametrically different strategies. Saudi Arabia is struggling to create the ideational appearance of a stronger GCC unity vis-a-vis popular Arab uprisings and Islamic dissidents.

This article is divided into three parts. In the first part, I outline the formation of the GCC as a symbolic organisation in the 1980s. Then, I turn to the two most important actors in the Arab Gulf, namely Saudi Arabia and Qatar, and describe the basis for their foreign policy strategies. In the last part, I analyse three case studies: the deployment of GCC troops to Bahrain, the bid to change the GCC to a Gulf Union and the search for a common GCC strategy against the Muslim Brotherhood. I focus on the Muslim Brotherhood and do not examine the similarly different threat perceptions between Saudi Arabia and Qatar towards fundamental Islamist groups operating in Syria and Iraq.

\section{The GCC as a Response to Ideational Threats}

The focus on identity is fruitful because the ruling families in the Arab Gulf base their legitimacy and thus the survival of their regimes on ideational politics. An internal or external threat to their ideational legitimacy could mean an end to their rule. The assumption of rational calculations by the political actors is insufficient in the case of the Gulf region. Here, decision-making is highly dependent on the personal choices and strategies of the ruling elite, but domestic,

Linda Berger has completed her MSc in Middle East Politics at SOAS University of London, in the last year. She is currently pursuing Arabic language studies in Amman, Jordan. regional and international norms and identities constrain the range of decisions Arab Gulf regimes can make (Hinnebusch 2003: 114). The Arab Gulf monarchies share legitimacy based on variations of a tribal-paternalistic cradle-to-grave welfare state and authoritarian political systems (see: Patrick 2011: 33-34). ${ }^{1}$ Therefore, the ruling families share the perception that anti-authoritarian political systems are a threat. However, the Arab Gulf monarchies differ, among others, in their historical experiences and political culture, which lead to different strategies of regime survival (Barnett and Gause 1998: 165). This is particularly evident in their strategies towards the challenges posed by the Arab uprisings.

In 1981, the GCC was established as a symbolic organisation. The GCC member states agreed on the construction of a common Gulf identity to counter the threatening ideologies of the socialist PanArabism of Iraq and of Iran's pan-Islamic 'export of the revolution' (Legrenzi 2011: 30-31). Both ideologies supported the overthrow of monarchies. Inter-state cooperation was not aimed at integration, but at reinforcing a Gulf identity (Barnett and Gause 1998: 168). ${ }^{2}$ The smaller GCC members resisted further cooperation for fears of cementing Saudi hegemony. The symbolic function was the smallest common denominator. The monarchies shared the perception that an alternative Gulf identity could weaken Iran's ideological reach in the Gulf monarchies' internal affairs. The GCC was an instrument to enhance the stability of the Arab Gulf monarchies.

\section{Saudi Arabia and Qatar: Common Aims, Different Strategies}

In the 1980s, the smaller Gulf states followed the Saudi lead to a certain extent. During the Arab uprisings, however, strategies of regime survival are diametrically different. Saudi Arabia is

1 Some scholars view the formation of the GCC as a natural process of countries with the same social, economic, political and historical features coming together (see: GCC charter). While some economic and cultural cooperation existed prior to the GCC formation, most scholars consider this automatism as being false. The ruling families used the image of societal homogeneity to justify the formation of the GCC (Barnett and Gause 1998: 165)

2 Cooperation focused on economic cooperation, where significant steps have been made. The GCC has established a Free Trade Area with limited free movement of services, labour and capital in 1983. A common market was established in 2008. The ultimate goal of a monetary union has not been achieved yet, and two deadlines in 2005 and 2010 have already been missed. Focuses on national economic development strategies and bilateral trade agreements have hampered deeper economic cooperation (Puig and al-Haddad 2011). 
not the uncontested regional coordinator (Kostiner 2009: 417) anymore; the smaller Gulf countries, with Qatar leading the way, have become more assertive.

The other four GCC members of Bahrain, Kuwait, Oman and the UAE have different strategies and constraints. Bahrain is relatively poor by GCC standards and thus depends on Saudi Arabia with whom it shares the fear of Shia uprisings in the country. The Kuwaiti ruling family is trying to navigate an ever more assertive parliament (see: Tétreault 2009). Oman rejects the Saudi's anti-Shia rhetoric due to its pluralistic tradition and good historical and economic ties with Iran (al-Rasheed 2013). The United Arab Emirates, consiting of six different Emirates, pursues a hard line against popular and Islamic dissidents. Dubai, one of the constituent emirates of the UAE, has close economic ties with Iran, but seems prepared to follow Abu Dhabi's lead, another constituent emirate (Davidson 2013: 174-175). Depending on specific foreign policy strategies they may decide to silently accept or follow the Saudi lead.

Saudi Arabia actively seeks to counter the popular effects of the Arab revolts and return to the regional status quo ante (Roberts 2014). The counterrevolution is two-pronged: Domestically, the ruling family attempts to maintain the comprehensive welfare state through financial and social welfare incentives under the assumption that their citizens' political indifference can be bought (Kamrava 2012: 98). ${ }^{3}$ Saudi Arabia spent $\$ 130$ bn to pay its civil servants two months' salary extra (Kamrava 2012: 98) and built new homes for \$60bn (Murphy 2011). In authoritarian Arab states, the public sector is an important but increasingly precarious means to placate citizens with easy and well-paid jobs. ${ }^{4}$ Moreover, the ruling family rigorously suppresses even the slightest challenge to the ideational basis of their rule by domestic dissidents (Kamrava 2012: 97).

Regionally, Saudi Arabia purses a more proactive foreign policy in reaction to the Arab uprisings. The threat perception did not change with the uprisings, only the urgency with which the Kingdom pursued its foreign policy changed (Sunik 2014). As before, movements which offer an alternative political system are seen as a threat to the legitimacy of the Kingdom; this includes Shia Iran and the Muslim Brotherhood, which is active in many Arab countries. Both propagate inclusive Islamic political systems, a more democratic alternative to the monarchical system in the Arab Gulf. Why this urgency? First, the ruling family can no longer depend on the United States to support "moderate" authoritarian rulers. Instead, the United States no longer backed its long-term allies in the region, such as Hosni Mubarak, started diplomatic negotiations with Saudi Arabia's nemesis Iran and would not follow through with threats of military action in Syria as of August 2014 (Sunik 2014: 2). Second, the Kingdom feared a further spreading of protests and toppling of long-standing authoritarian leaders. To stop further precedents influencing domestic dissidents, the

3 Academic scholarship uses rentierism to partly explain the survival of the Arab Gulf monarchies. For the theoretical framework, see: Beblawi and Luciani 1987. For a critical view, see: Herb 2004.

4 Kuwait increased the salaries of public servants by 115\% (Kamrava 2012: 98). In Oman, the ruler created 50,000 new public service jobs and granted a jobseeker's allowance of $\$ 390$ per month. Bahrain promised new homes for \$6.6bn (Murphy 2011). The GCC promised \$20bn to the latter two (Kamrava 2012: 98).
Kingdom had to start a 'counter-revolution' (Kamrava 2012). In looking for a tool to give Saudi foreign policy more clout domestically, regionally and internationally, the Kingdom attempts to retrieve the GCC as a symbolic organization. A united organisation of Arab (Gulf) monarchies is to present a symbolic counter-ideology to the popular ideologies of dissidents shaking other Arab countries.

The Qatari ruling family pursues the foreign policy strategy of 'branding'. Before the uprisings, they focused on branding themselves as valuable members of the so-called international community (Peterson 2006). Qatar aims to construct the idea of being valuable and thus evoking a domestic feeling of pride linked to the regime (Haykel 2013: 7). Through various public mediation efforts - for example in Yemen and Lebanon - Qatar sought to present itself as an impartial mediator in the region (Kamrava 2011: 542). Prestigious projects, such as the FIFA World Cup 2022, bring the country on the map for foreign investments and thus help Qatar diversify its economy (Salem and de Zeeuw 2012). This assertive foreign policy is a dramatic change from the 1990s, when the Emirate was "a Saudi vassal" (Kamrava 2011: 541). Qatar has become a regional competitor to Saudi Arabia in influence.

With the Arab uprisings, Qatari branding changed from neutrality to partisanship for the popular protests, particularly for the Muslim Brotherhood (Salem and de Zeeuw 2012). While other GCC member states witnessed popular protests, the Qatari regime did not witness any domestic challenges as the cradle-to-grave welfare state is so strong and the small society so "close-knit" (Roberts 2014; Kamrava 2012: 97). As domestic dissidents are almost non-existent, the regime feels secure enough to support the anti-monarchical Muslim Brotherhood. The former Emir of Qatar Hamad bin Khalifa Al Thani, and to a lesser extent his son and successor Tamim bin Hamad $\mathrm{Al}$ Thani, personally want to side with popular opinion in the Arab world and form alliances with potential new leaders in the Arab world (Hauslohner 2013). In the last few months, however, the tide has turned against Qatar's new allies. How have Qatar and Saudi Arabia cooperated within the GCC despite these different strategies towards the Arab uprisings?

\section{The GCC and the Arab Uprisings: A new Dawn of Unity?}

The Arab uprisings started in Tunisia in 2011 and quickly spread to other authoritarian states in the Arab world. For the GCC countries, preoccupied with regime survival, the Arab uprisings are the "most serious crises since the Iranian revolution" (Kamrava 2012: 97). Have the Gulf monarchies found a common strategy against the uprisings before they lead to large-scale protests against their own rule?

\subsection{The Peninsula Shield Force in Bahrain: A GCC-wide Call to Arms?}

The monarchies of the Arab Gulf also witnessed popular protests to some extent. Most protesters were not calling for the resignation 
of rulers, but for better jobs and greater political participation. Only in Bahrain did the protests lead to the deployment of the GCC's Peninsula Shield Force to 'protect' a fellow member from 'external interference'. Was this a collective reaction to a common ideational threat by the six member states of the GCC?

The protests in Bahrain, which began in February 2011, were inspired by protests in Egypt forcing Hosni Mubarak from power after almost three decades. Both the Bahraini and Saudi regime painted the protests by the Bahraini Shia majority as an extension of Shia-Iran meddling in another sovereign country (Kamrava 2012: 99). The Iranian government has attempted to repaint the Arab uprisings as an "Islamic awakening" in the spirit of the Iranian revolution (Sunik 2014: 4-5). This narrative has reinforced Saudi and Bahraini concerns about Iranian influence on domestic dissidents. Al-Wafaq, the main Shia opposition movement in Bahrain, has denied external involvements. Commentators support this (Sunik 2014:4; Richter 2011: 5). Nevertheless, Saudi Arabia and Bahrain could discredit the protests in the eyes of the rest of their citizens. The ruling families in Saudi Arabia and Bahrain have fostered anti-Shia sentiments in the public for years. The prevalence of Shia protesters is due to the political, economic and social discrimination against Shias by the Sunni Bahraini ruling family (Richter 2011: 5). The rhetoric of an Iranian interference allowed for the deployment of the GCC's Peninsula Shield Force against domestic protesters.

The Bahraini government officially requested the Peninsula Shield Force $^{5}$ in March 2011 (Davidson 2013: 206). A closer look reveals that the 'GCC-wide' force did not include troops from all GCC member states. Only Saudi Arabia sent more than 1,500 National Guard troops and the UAE "some of its police units" (Patrick 2011: 15). Kuwait seemed "to have sent a naval craft in order to show solidarity with its fellow Sunni regimes without overtly antagonizing its numerically significant Shia minority" (Patrick 2011: 15). ${ }^{6}$ Shia members of parliament are an important part of the pro-ruling family group in parliament (Khalaf 2013). Oman did not contribute any troops, because they did not want to support Saudi rhetoric of a Shia uprising fuelled by Iran. After the deployment, Qatari officials claimed that they also contributed troops (Ahram Online 2011). Although the official Qatari news agency released the information, the validity of the information remains unclear; the report was not widely picked up by other news outlets. If true, Qatar seemed to demand due diligence for being part of a GCC operation, although the Emirate does not share Saudi and Bahraini fears of domestic Shia uprisings. The Qatari ruling family seems to see no contradiction in supporting protesters outside the GCC and conservative monarchies within the GCC. The Kuwaiti naval ships and Omani silence can be interpreted as tactical conformity to Saudi attempts of GCC-unity in Bahrain.

The GCC was used as an "ideational cover" (Patrick 2011: 15) to justify the deployment (Davidson 2013: 206). The GCC gave the crackdown against protesters a multilateral and rightful covering; the GCC appeared to be united in coming to the aid of a fellow member against external aggressors threatening the survival of the Bahraini monarchy. Saudi Arabia spearheaded both the deployment and the rhetoric justification, and the UAE followed the Saudi lead.

5 The Peninsula Shield Force was established in the mid-1980s to create a symbolic 'myth of self-reliance' against the much greater manpower of Iran and Iraq (Legrenzi 211: 75; Barnett and Gause 1998: 174; Patrick 2011: 14).

6 This deployment is not mentioned by Davidson (2013: 205-209).
It highlighted Saudi determination to counter the ideational threat of popular protests and Saudi willingness to exploit the GCC to colour its 'counter-revolution' as multilateral action.

\subsection{The Gulf Union: A Rejuvenated GCC?}

In December 2011, the Saudi King proposed the formation of a Gulf Union. This was the second Saudi proposal after the lukewarmly received invitation for membership to Jordan and Morocco a few months prior. The Saudi Crown Prince Salman Bin Abdul Aziz vaguely claims that the Gulf Union would entail a "strong union with integrated economies, a joint foreign policy and a common defence system" (quoted in: Al Arabiya 2012). Such an elevation from council to union would be a signal for closer unity; however, its implementation is unlikely, despite a Saudi prince calling it "inevitable" (quoted in: Habib 2013).

The idea of an integrated Gulf Union is met with resistance by the smaller Gulf states, with the exception of Bahrain, which depends on Saudi Arabia. They fear that the Union's largest member Saudi Arabia would be "swallowing its smaller neighbours" (Shaikh 2013). Kuwait is split between parliament and the ruling family. In February 2012, the Kuwaiti speaker of parliament opposed a union (Alsayed 2013). According to Bruce Riedel (2013), some "Kuwaiti royals may be sympathetic" to the idea. Oman openly and vigorously objected to the union (Habib 2013). The UAE and Qatar also objected to a Union, fearing Saudi dominance (Hammond 2012). The ruling families of the smaller Gulf states are united in their fear of Saudi dominance as a Gulf Union would weaken their legitimacy considerably.

A Union would enable Saudi Arabia, the state with the largest economy and population, to dominate the Union and thus dictate its foreign policy. Saudi Arabia feels that it can only counter the ideas of a popular Islamic political system through a decisive and unified front. However, Saudi Arabia has neither the ideational nor the material authority to demand that the smaller Gulf states cede their influence to the Saudi ruling family. Instead, the smaller Gulf states are united in their strong and vocal opposition of such a Union. A Union within the GCC with Saudi Arabia and Bahrain seems more likely.

\subsection{The Muslim Brotherhood: Threat or Opportunity?}

The Muslim Brotherhood is the bone of contention between Saudi Arabia and Qatar. Saudi Arabia perceives the popular Sunni Islamic group and its alternative model of Islamic governance as a threat to its regime. Qatari legitimation and regime survival are not based on Islamic leadership and the Emirate has no Islamist opposition to speak of; they do not perceive the Muslim Brotherhood as an internal threat; the Qatari branch of the Muslim Brotherhood "disbanded itself in 1999" (al-Buluwi 2014b). The different threat perceptions lead to different strategies.

Qatar's regional support of the Muslim Brotherhood is farreaching. Besides financial support, it is granting exile to many of its members. These include Yusuf al-Qaradawi, an Islamic 
scholar with a popular show on Al Jazeera Arabic, and Khaled Mashal, the exiled political leader of Hamas. Because of this, Saudi Arabia and the UAE see Qatar as a regional "launching pad for dissidents and activities" (al-Rasheed 2014). Qatar denies any internal interference (al-Buluwi 2014b). As the ruling family does not face domestic Islamist opposition, the family does not fear that its external support of the popular Islamic movements could threaten its monarchical political system. For Qatar, the Muslim Brotherhood is an opportunity to represent itself as a supporter of Arab popular opinion.

The rift extends to the other GCC member states. Bahrain is not as opposed to the Muslim Brotherhood as Saudi Arabia, with whom it normally sides (Kamrava 2012: 102). Bahrain's local branch of the Sunni Muslim Brotherhood is seen as a valuable ally against Shia protests (Hatlani 2014). Kuwait is also more tolerant; members of the local Muslim Brotherhood have served in government and have been elected to parliament (Dickinson 2014). Only the UAE shares Saudi Arabia's strong condemnation of the Muslim Brotherhood. The country has arrested numerous dissidents, including Qataris (Kechichian 2014). The UAE's de facto leader, Mohammad bin Zayed, the Crown Prince of Abu Dhabi, has a particular "deep distrust and dislike" (Roberts 2014) of the Muslim Brotherhood. Saudi Arabia has only the UAE as an unequivocal supporter in its campaign against the Muslim Brotherhood; Bahrain may follow to a certain extent.

The extent of the rift was highlighted in Egypt, where Qatar and Saudi Arabia were on different political sides after the toppling of Hosni Mubarak. Qatar financially supported Muslim Brotherhood-backed President Morsi with an \$8bn aid package. Saudi Arabia, together with Bahrain and the UAE, supports the "counter-revolutionary military republicanism" (al-Rasheed 2014) of Abd al-Fattah as-Sisi. After the coup d'état in July 2013, Abd al-Fattah as-Sisi banned the Muslim Brotherhood as a political group and received over \$20bn from Saudi Arabia and the UAE (al-Buluwi 2014a). The public rift pre-empted any attempts by Saudi Arabia to construct a collective GCC approach to Egypt.

In March 2014, the rift culminated in the withdrawal of the Saudi, Bahraini and Emirati ambassadors from Qatar. The three countries accused Qatar of violating an agreement reached in November 2013. According to sources, the agreement included two vague points: first, no support for movements or individuals who threaten the stability or security of a GCC member state, which means the Muslim Brotherhood; ${ }^{7}$ second, end any support to hostile media, referring to the anti-Saudi broadcasts by Yusuf al-Qaradawi on Qatar-based al-Jazeera Arabic (al-Rasheed 2014; Kechichian 2014). This agreement would have meant an overturn of current Qatari foreign policy.

Saudi Arabia hopes to capitalise on the moment of Qatari weakness. First, they hope that the new young Emir, in power since June 2013, is easier to influence than his father; second, Qatar's regional clout has diminished with old elites reasserting their power, such as in Egypt; third, Saudi Arabia has reasserted itself as the official Gulf supporter of the Syrian opposition as Qatar's support to hard-line Islamist rebels has marginalised the country internationally (Hauslohner 2013). With the November 2013 agreement and the extreme diplomatic action, Saudi Arabia

7 A few days later, Saudi Arabia and the UAE declared the Muslim Brotherhood and its local branches a terrorist organisation (Roberts 2014). hopes to "cow Qatar and its renegade foreign policy under control" (Roberts 2014). Only when Qatar officially follows Saudi threat perception can the Saudi ruling family adequately instrumentalise the GCC as a symbolic organisation of Arab Gulf unity.

\section{Conclusion}

The GCC did not become a symbol of unity during the Arab uprisings. Instead, the GCC has become a symbol of discord. All three cases - the deployment of GCC troops to Bahrain, a new Gulf Union and the struggle against the Muslim Brotherhood - demonstrated attempts by the Saudi ruling family to enforce its threat perception and to instrumentalise the GCC as a symbol of unity. Only the earliest attempt, the deployment of the GCC forces in Bahrain, was uncontested by the other GCC member states; despite Kuwait and Oman not being participants. Saudi Arabia continues to lobby hard for an unspecified Gulf Union. Saudi Arabia's and the UAE's confrontational policy towards Qatar in the Muslim Brotherhood causa casts GCC unity towards the Arab uprisings into doubt.

The GCC was to portray the Arab (Gulf) monarchies as ideationally different from the rest of the Arab world in order to lessen the ideational inspirations Gulf citizens could gain from upheavals in the rest of the Arab world. However, Saudi Arabia has failed to instrumentalise the GCC for their counterrevolution against popular Islamic political systems. The smaller Gulf states have different individual regime survival strategies and face domestic constraints by powerful parliaments. The GCC has only been successful in forging a common Gulf identity among its citizens and not among its ruling families.

\section{Bibliography}

Ahram Online. 2011. Qatar has sent troops to Bahrain.18 March 2011: http://english.ahram.org.eg/ NewsContent/2/8/7988/ World/Region/Qatar-has-sent-troops-to-Bahrain.aspx (accessed 1 September 2014).

Al Arabiya. 2012. Gulf leaders agree on unified military command at Bahrain summit. 25 December 2012: http://english.alarabiya. net/articles/2012/12/25/257017.html (accessed 1 September 2014).

al-Buluwi, Abdulmajeed. 2014a. Saudi, UAE coordination signals differences with Qatar. In: Al-Monitor, 26 May 2014: http://www.almonitor.com/pulse/originals/2014/05/saudi-uae-joint-committeeregional-policy-libya-egypt.html (accessed 1 September 2014).

al-Buluwi, Abdulmajeed. 2014b. Saudi-Qatar divide means reset for GCC. In: Al-Monitor, 7 March 2014: http://www.al-monitor. com/pulse/originals/2014/03/gulf-gcc-saudi-arabia-qatarmuslim-brotherhood-uae.html (accessed 1 September 2014).

al-Rasheed, Madawi. 2013. Omani rejection of GCC union adds insult to injury for Saudi Arabia, in: Al-Monitor, 9 December 2013: http://www.al-monitor.com/pulse/originals/2013/12/omanrejects-gcc-union-insults-saudi-arabia.html\#ixzz3ASUDPmxU (accessed 1 September 2014).

al-Rasheed, Madawi. 2014. Saudi-Qatar tensions divide GCC. In: Al-Monitor, 6 March 2014: http://www.al-monitor.com/ 
pulse/originals/2014/03/saudi-qatar-gcc-tensions-islamist.html (accessed 1 September 2014).

Alsayed, Wafa. 2013. Bridging the Gulf: where Kuwait stands on the GCC Union. In: Al Arabiya, 12 May 2013: http://english. alarabiya.net/en/special-reports/bridging-the-gulf/ 2013/05/12/ Bridging-the-Gulf-where-Kuwait-stands-on-the-GCC-Union. html (accessed 1 September 2014).

Barnett, Michael and Gause III, F. Gregory. 1998. Caravans in opposite directions. Society, state and the development of a community in the Gulf Cooperation Council. In: Emanuel Adler and Michael Barnett (eds.). Security Communities. Cambridge: Cambridge University Press, 161-197.

Bebalwi, Hazem and Luciani, Giacomo (eds). 1987. The Rentier State. London: Croom Helm.

Davidson, Christopher. 2013. After the Sheikhs. The Coming Collapse of the Gulf Monarchies. London: Hurst.

Dickinson, Elizabeth. 2014. Saudi action puts Muslim Brotherhood in Kuwait on spot. In: Al-Monitor, 10 March 2014: http://www.al-monitor.com/pulse/originals/2014/03/ muslim-brotherhood-kuwait-saudi-terror.html\#ixzz3C4leHQ21 (accessed 1 September 2014).

Habib Toumi. 2013. Gulf union is inevitable: Saudi Prince Turki Al Faisal. In: Gulf News (UAE), 8 December 2013: http:// gulfnews.com/news/gulf/oman/gulf-union-is-inevitable-saudiprince-turki-al-faisal-1.1264725 (accessed 1 September 2014).

Hammond, Andrew. 2012. Analysis: Saudi Gulf union plan stumbles as wary leaders seek detail. In: Reuters, 17 May 2012: http://www.reuters.com/article/2012/05/17/us-gulf-unionidUSBRE84G0WN20120517 (accessed 1 September 2014).

Hatlani, Ibrahim. 2014. Bahrain Between its Backers and the Brotherhood. In: Sada (Carnegie Middle East program), 20 May 2014: http://carnegieendowment.org/sada/2014/05/20/bahrain-betweenits-backers-and-brotherhood/hb8a (accessed 1 September 2014).

Hauslohner, Abigail. 2013. Qatar loses clout amid fading Arab Spring. In: The Washington Post, 13 November 2013: http:// www.washingtonpost.com/world/middle_east/qatar-loses-cloutamid-fading-arab-spring/2013/11/13/f3072b64-46ea-11e3-95a93f15b5618ba8_story.html (accessed 1 September 2014).

Haykel, Bernard. 2013. Saudi Arabia and Qatar in a Time of Revolution. CSIS (Center for Strategic and International Studies) Middle East Program, Gulf Analysis Paper.

Herb, Michael. 2004. No Representation without Taxation? Rents, Development, and Democracy. In: Comparative Politics, $37: 3,297-317$.

Hinnebusch, Raymond. 2003. The international politics of the Middle East. Manchester: Manchester University Press.

Kamrava, Mehran. 2011. Mediation and Qatari Foreign Policy. Middle East Journal, 65:4, 539-556.

Kamrava, Mehran. 2012. The Arab Spring and the Saudi-Led Counterrevolution. Orbis, 56:1, 96-104.

Kechichian, Joseph A. 2014. Can Kuwait save the GCC? In: Al-Jazeera, 7 March 2014: http://www.aljazeera.com/indepth/ opinion/2014/03/can-kuwait-save-gcc-201436105011872371. html (accessed 1 September 2014).

Khalaf, Abd al-Hadi. 2013. GCC Members Consider Future of Union. In: Al-Monitor (first published in Arabic in as-Safir (Lebanon)), 14 January 2013: http://www.al-monitor.com/ pulse/politics/2013/01/saudi-arabia-gcc-announcement.html (accessed 1 September 2014).

Kostiner, Joseph. 2009. Saudi Arabia and the Arab-Israeli Peace Process: The Fluctuation of Regional Coordination. In: British Journal of Middle Eastern Studies, 36:3, 417-429.

Legrenzi, Matteo. 2011. The GCC and the International Relations of the Gulf. Diplomacy, Security and Economic Coordination in a Changing Middle East. London, New York: I.B. Tauris.

Murphy, Caryle. 2011. GCC to set up \$20bn bailout fund for Bahrain and Oman, in: The National (UAE), 11 March 2011: http://www.thenational.ae/news/world/middle-east/gcc-toset-up-20bn-bailout-fund-for-bahrain-and-oman (accessed 1 September 2014).

Patrick, Neil. 2011. The GCC. Gulf state integration or leadership cooperation? Kuwait Programme on Development, Governance and Globalisation in the Gulf States, Research Paper 19.

Peterson, J. E. 2006. Qatar and the World. Branding for a MicroState. Middle East Journal, 60:4, 732-748.

Puig, Gonzalo Villalta and al-Haddad, Bader. 2011. The Constitutionalisation of Free Trade in the Gulf Cooperation Council. In: Arab Law Quaterly, 25, 311-324.

Richter, Thomas. 2011. 30 Jahre Golfkooperationsrat. Schützt Mitgliedschaft vor Revolution? German Institute for Global and Area Studies, GIGA Focus Nahost, 5.

Riedel, Bruce. 2013. Saudi Arabia moving ahead with Gulf union. In: Al-Monitor, 22 December 2013: http://www.al-monitor. com/pulse/originals/2013/12/saudi-arabia-gcc-unity-omanopposition-king-abdullah.html (accessed 1 September 2014).

Roberts, David. 2014. How Personal Politics Drive Conflict in the Gulf. In: From the Potomac to the Euphrates (Blog by Steven A. Cook), 6 May 2014: http://blogs.cfr.org/cook/2014/05/06/how-personalpolitics-drive-conflict-in-the-gulf/ (accessed 1 September 2014).

Salem, Paul and de Zeeuw, Huib. 2012. Qatari Foreign Policy: The Changing Dynamics of an Outsize Role. In: Carnegie Middle East Center, 31 December 2012: http://carnegie-mec. org/2012/12/31/russia-and-west-need-to-rediscover-each-otherin-2013/fiay (accessed 1 September 2014).

Shaikh, Salman. 2013. A People's Agenda for Gulf Co-operation. In: Brookings, 15 January 2013: http://www.brookings.edu/ research/opinions/2013/01/15-gulf-cooperation-shaikh (accessed 1 September 2014).

Sunik, Anna. 2014. Alte Ziele, neue Taktik - Saudi Arabiens außenpolitischer Aktivismus. German Institute for Global and Area Studies, GIGA Focus Nahost, 3.

Tétreault, Mary Ann. 2009. Kuwait. Slouching towards Democracy?. In: Joshua Teitelbaum (ed.). Political Liberalization in the Persian Gulf. New York: Clumbia University Press, 107-132. 